УДК 338.1

\title{
СУЧАСНІ НАПРЯМКИ ФОРМУВАННЯ СИСТЕМИ УПРАВЛІННЯ РОЗВИТКОМ ПІДПРИЄМСТВ ХАРЧОВОЇ ГАЛУЗІ
}

\section{MODERN DIRECTIONS OF FORMATION MANAGEMENT SYSTEM FOR THE ENTERPRISES' DEVELOPMENT IN THE FOOD INDUSTRY}

\author{
Зєніна-Біліченко Антоніна Сергіївна \\ кандидат економічних наук, доцент, \\ Національний університет харчових технологій \\ ORCID: https://orcid.org/0000-0001-6147-2827 \\ Гуль Анна Юріївна \\ магістрант, \\ Національний університет харчових технологій \\ ORCID: https://orcid.org/0000-0002-5747-8908 \\ Zienina-Bilichenko Antonina, Hul Anna \\ National University of Food Technology
}

\begin{abstract}
Стаття присвячена актуальним питанням визначення понятійного та категоріального апарату процесу фрормування системи управління розвитком підприємств харчової галузі. Проаналізовано та систематизовано механізм розвитку за критеріями, складовими, типами та напрямами, визначено етапи процесу формування системи управління розвитком підприємств харчової промисловості та запропоновано організаційно-інфрормаційну модель розвитку. Окреслено подальші напрямки забезпечення формування загального результату діяльності суб'єктів господарювання на основі комплексного управління розвитком промислових підприємств за умови удосконалення економічного та організаційного механізмів управління діяльністю, досягнення довгострокових цілей підприємств та стабілізації економіки та підвищення рівня конкурентоспроможності національних підприємств та економіки держави на світовому ринку.

Ключові слова: система управління, розвиток, механізму розвитку господарської діяльності, організаційноінфрормаційна модель розвитку.
\end{abstract}

Статья посвящена актуальным вопросам определения понятийного и категориального аппарата процесса формирования системы управления развитием предприятий пищевой отрасли. Проанализирован и систематизирован механизм развития по критериям, составляющим, типам и направлениям, определены этапы процесса формирования системы управления развитием предприятий пищевой промышленности и предложена организационно-информационная модель его развития. Обозначены дальнейшие направления формирования результата деятельности хозяйствующих субъектов на основе комплексного управления развитием промышленных предприятий при усовершенствовании экономического и организационного механизмов управления деятельностью, достижении долгосрочных целей предприятий и стабилизации экономики, а также повышения уровня конкурентоспособности национальных предприятий и экономики страны на мировом рынке.

Ключевые слова: система управления, развитие, механизм развития хозяйственной деятельности, организационно-инорормационная модель развития.

Under modern conditions the study of areas of search for reserves to increase the efficiency of enterprises, development of methodological principles for using strategic opportunities for managing the stability of the enterprise taking into account technological features of production and sale of finished products, ensuring the intensification of enterprises and increasing the competitiveness of the food industry is getting are remarkable relevance. The purpose of the article is to study the theoretical foundations and methodological recommendations for the formation of management system for the development of food industry, paying significant attention to organizational and economic approaches, determining the characteristics, types and elements of the mechanism of economic development, its stages and principles. The methodological basis of the study is the fundamental provisions of economic theory, the work of domestic and 
foreign scientists in management, business economics. To solve the task the following methods were used: method of system analysis to study the results of the implementation management mechanisms for the development of food industry enterprises and assess their impact on performance, analogies for management decisions, graphical method to illustrate and visualize the results. In this article current issues of defining the conceptual and categorical apparatus of the process of forming the management system of food industry development were analyzed, areas of formation and development of the enterprise, opportunities to use its potential, formation of organizational and information potential were identified as well as mechanisms of development were systematized by criteria, components, types and directions, the stages of the process of forming a management system for the development of food industry enterprises were determined. So the development of the enterprise is a rather complex concept, which on the basis of the analysis is proposed to be understood as a long-term set of quantitative and qualitative changes in the enterprise that improve its condition by increasing the company's potential, developing the company's ability to counteract the negative effects of the external environment and their competitiveness. The mechanism of formation of organizational and informational model of food enterprises development is offered, which allows to promote the solution of strategic tasks aimed at ensuring stable sales, constant search of new markets, fight against competition, which can be practically implemented in food enterprises. Therefore, the most important practical significance of the study is to form a mechanism of management as a holistic system, and it allows to use its corporate laws, the degree of compliance with economic relations and interests, to identify relationships and interdependencies between its forms, to determine the nature of cumulative regulatory impact on potential opportunities, to outline areas for overcoming crisis challenges.

Keywords: management system, development, mechanism of economic activity development, organizational and information model of development.

Постановка проблеми. В сучасних умовах господарювання в Україні найбільшою ланкою представлена харчова промисловість, яка налічує більше ніж п'ятдесят галузей та спеціалізованих виробництв, таких як спиртові, пивоварні, хлібопекарні, цукрові, кондитерські, молочні, м'ясні, олійно-жирові та овочеві підприємства. Специфрікою харчової галузі можна вважати її постійне динамічне зростання при будь-яких умовах, що забезпечує привабливий інвестиційний клімат. Тому, незважаючи на кризовий стан економіки, на сьогодні інвестування в дану галузь $€$ досить актуальним, оскільки продукти харчування $€$ стратегічними товарами та необхідними умовами існування людини.

В результаті зміни економічних умов фрормування ринкових відносин, глобальної перебудови структур управління, принципів господарювання значна частина вітчизняних підприємств втратили конкурентоздатність. Причини чого криються в недоліках стратегічного планування та бачення майбутнього стану підприємства, невідповідні тактичні засоби, що покликані попереджати і прогнозувати зміни в нестабільному зовнішньому середовищі, а також диспропорції внутрішнього середовища підприємства та неспроможність швидко реагувати на його зміну, порушення кооперативних зав'язків.

Процес фрормування системи розвитку підприємств харчової промисловості $є$ частиною загальної системи управління підприємством, що забезпечує вплив на чинники, від яких залежить загальний результат діяльності суб'єкта, і розпочинається 3 характеристики його складових та визначення послідовності його здійснення на основі системного підходу [2].
Аналіз останніх публікацій. Дослідженням питань сутності та механізму формування систем розвитку підприємств та управління ним присвячені наукові праці О. Амоши, А. Гальчинського, В. Гейця, В. Гончарова, Г. Губерної, В. Дорофрієнка, О. Кузьміна, С. Лукіна, П. Лайка, А. Мельника, О. Пащенка, С. Поважного, А. Савченко, М. Чумаченка та інших вчених, але ряд аспектів практичного вирішення проблеми формування та регулювання системи управління розвитком підприємств харчової промисловості залишаються дискусійними та актуальними для сучасності та потребують подальшого вивчення.

Виділення невирішених раніше частин загальної проблеми. Вивчення теоретичних положень та методичних рекомендацій з удосконалення механізмів фрормування системи управління розвитком підприємств $€$ дуже актуальним завданням, що потребує вирішення 3 урахуванням сучасних тенденцій глобалізації та інтеграції підприємств харчової промисловості. Дослідження напрямків пошуку резервів зростання ефрективності діяльності підприємств, розроблення методичних підходів до визначення стратегічних можливостей управління фрінансовою стійкістю підприємства, фуункціонування організаційно-економічного механізму підприємств 3 врахуванням технологічних особливостей виробництва та реалізації готової продукції, дослідження впливу оподаткування на розвиток підприємств з метою досягнення балансу між економічними інтересами держави та суб'єктів господарювання забезпечить активізацію діяльності підприємств та сприятиме зростанню їх есрективності. Особливу актуальність ці питання мають для підприємств хар- 
чової промисловості, де подібним розробкам практично не приділялася увага.

Формулювання цілей статті (постановка завдання). Враховуючи актуальність дослідження, мета статті полягає в розробці теоретичних та методичних засад і рекомендацій щодо формування системи управління та механізму розвитку діяльності підприємств харчової промисловості з врахуванням організаційних та економічних підходів, визначенні концепції та характеристики видів та складових механізму розвитку господарської діяльності, його етапів та складових.

Виклад основного матеріалу дослідження. В умовах переходу до інноваційної економіки та економіки знань активізується роль науково-технологічного розвитку, який $€$ основою вдосконалення соціально-економічних систем, тому необхідно приділити увагу й самому поняттю «розвиток» як цільовій фуункції дослідження.

Поняття «розвиток» $€$ достатньо складним поняттям, оскільки воно вміщує набір сучасних характеристик та необхідних у майбутньому практичних настанов, вимагає напрацювання організаційно-економічних та методичних підходів до процесу управління соціально-економічним зростанням $[1 ; 3 ; 6 ; 7]$. Узагальнення підходів до визначення поняття «розвиток» дозволяє зробити висновок, про визначення розвитку як процесу змін, які можуть бути кількісними, якісними та структурними. Кількісні зміни характеризуються збільшенням або зменшенням складових частин цілого, яке виражається зміною їх числових значень, що призводять на певних етапах до якісного стрибка, а структурні зміни - це зміни відношення складових частин, які не обов'язково повинні супроводжуватися збільшенням або зменшенням їх кількості. Між тим структурні зміни також можуть призводити до якісного стрибка. Тому можна вважати, що як кількісні, так і структурні зміни відіграють значну роль в якісних змінах. Отже, виходячи з узагальнення змісту теоретичних засад під розвитком підприємства можна розуміти процес, що відбувається з метою забезпечення підприємства науковими та дослідними розробками, які здатні перетворитися на інновації, в результаті яких можливе суттєве оновлення кількісних, якісних та структурних характеристик усіх сорер діяльності підприємства. Систематизація розвитку за критеріями характеру змін, джерела або першопричини розвитку, масштабу та складності об'єкта, форми розвитку, а також представлення суб'єкта розвитку щодо об'єкта розвитку є достатньо традиційною і відображається в сучасній науці, але дозволяє сорормувати нові критерії системати- зації розвитку - виділення векторів розвитку, їх кількість, комплексність змін, загальна характеристика змін, що дозволяють конкретизувати типи та напрями розвитку підприємства.

Таким чином, розвиток підприємства пропонується розуміти як довготривалу сукупність процесів кількісних та якісних змін в діяльності підприємства, які приводять до поліпшення його стану шляхом збільшення потенціалу підприємства, адаптації до зовнішнього середовища та внутрішньої інтеграції, що сприяє підвищенню здатності підприємства протидіяти негативним впливам зовнішнього середовища, його життєздатності та конкурентоздатності. Процес орормування механізму розвитку господарської діяльності підприємств харчової промисловості можна представити у вигляді послідовності пов'язаних між собою етапів (рис. 1).

В умовах сьогодення на підприємствах харчової промисловості однією з найгостріших проблем виявляється відсутність цілісної стратегії, спрямованої на забезпечення фрінансової стійкості, господарської діяльності підприємства та стійкого розвитку у перспективі. При цьому засобом фрормалізації аналізу суб'єктів господарювання стає розробка моделі, яка поєднує основні складові системи управління механізмом розвитку діяльності підприємств харчової промисловості: організаційну та інфоомаційну. Організаційні питання стосуються характеристики суб'єктів, об'єктів, мети, завдань, елементів та методичного забезпечення, а інформаційні охоплюють побудову інфрормаційної бази аналізу: визначення джерел інформації, характеристику інформаційного забезпечення та розроблення системи показників, за допомогою яких передбачається досліджувати об'єкт.

Організаційно-інорормаційна модель розвитку господарської діяльності підприємств харчової промисловості $\epsilon$ стислою характеристикою його об'єктів та суб'єктів, мети і завдань, системи показників, що визначають їх параметри, інсрормаційної бази, методів і прийомів перетворення економічної інфрормації, узагальнення результатів аналізу (рис. 2).

Взаємопов'язаність блоків в моделі дозволяє в процесі фрормування системи управління розвитком впливати на визначення мети та системи завдань, послідовне вирішення яких сприятиме досягненню поставлених стратегічних та оперативних цілей. Характеристика об'єктів аналітичної діяльності та основних параметрів дослідження, а також суб'єктів відповідних конкретних завдань, перелік показників, що дозволяють зробити всебічний аналіз об'єктів, з визначенням певних термінів три- 
Визначення та оцінка цілей, суб’єктів, об’єктів управління та їх елементів

Визначення методів впливу на чинники управління: засобів, методів, важелів, способів здійснення

Розробка стратегії забезпечення розвитку підприємств харчової промисловості

Реалізація та впровадження стратегії в діяльність підприємств харчової промисловості

Моніторинг: аналіз розвитку, контроль за виконанням завдань та досягнення цілей підприємства, коригування процесу реалізації стратегії

Рис. 1. Етапи процесу формування системи управління розвитком підприємств харчової промисловості

Джерело: [5]

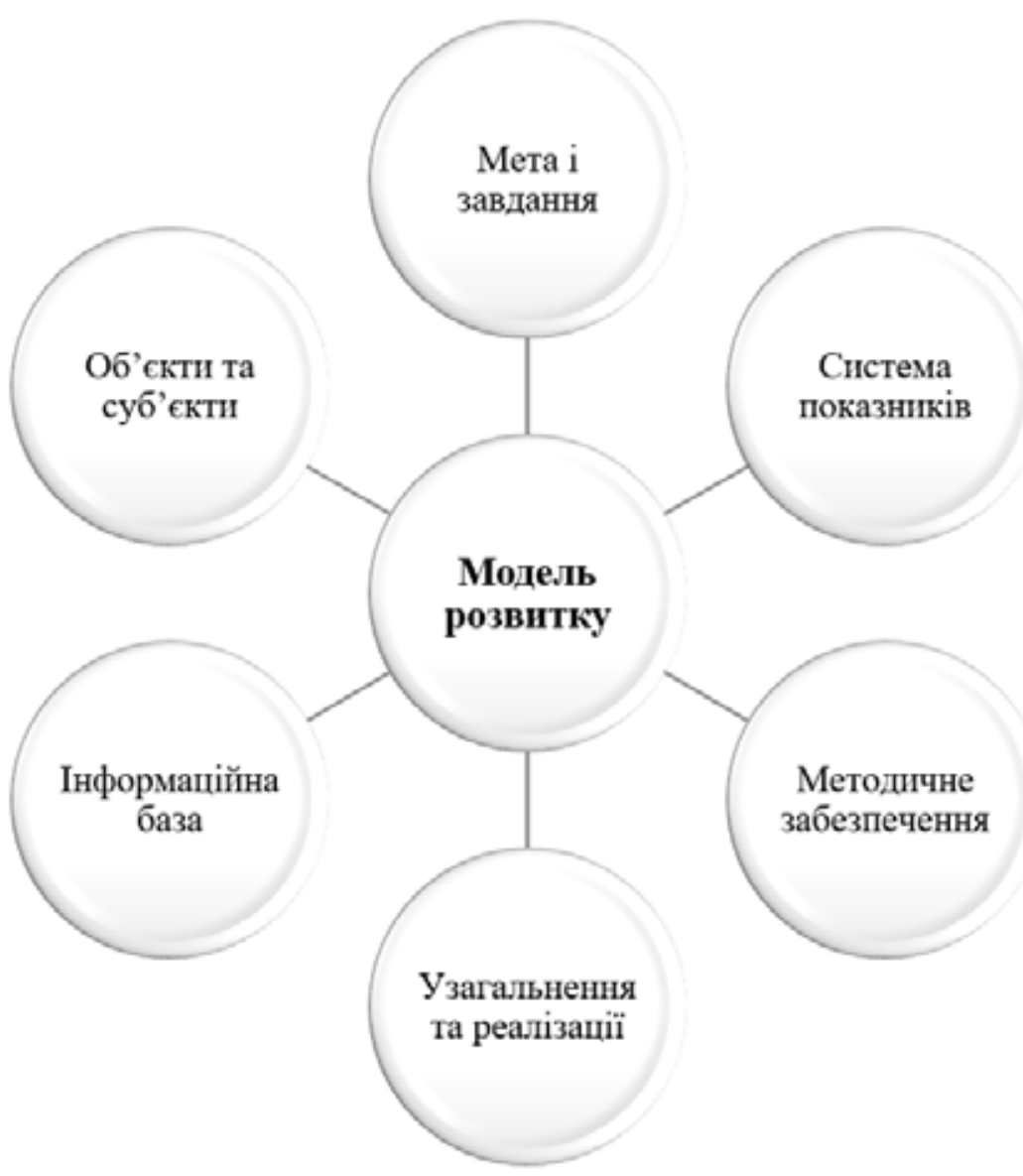

Рис. 2. Організаційно-інформаційна модель розвитку господарської діяльності підприємств харчової промисловості Джерело: [4] 
валості аналітичного періоду з використанням джерел утворення економічної інорормації, та характеристики методів та прийомів її обробки, яка завершується прийняттям управлінських рішень щодо подальшого фрормування системи управління розвитком підприємств.

Таким чином, фрормування системи та механізму управління розвитком підприємств харчової промисловості дозволить керівникам використовувати його для забезпечення стабільного фрункціонування та прогнозування розвитку підприємства в майбутньому. За умови удосконалення фрінансово-економічного механізму управління діяльністю підприємства стане можливим досягнення довгострокових цілей як самого підприємства, так і держави, а також стабілізація національної економіки та підвищення рівня конкурентоспроможності національної економіки на світовому ринку.

Аналіз діяльності підприємств харчової галузі доводить проблему відсутності стратегічних програм розвитку, необхідних для узгодження осно- вних напрямів роботи підприємств на перспективу. Ключовими елементами процесу розробки стратегії підвищення стабільності підприємств за умов формування системи управління розвитком на підставі даних статистичної та додаткових форм і видів звітності підприємства стає аналітичний баланс, на основі якого визначаються вихідні дані для розрахунку вибраних показників стійкості підприємства, виявлення і класифікація фракторів, які мають вплив на показники результатів діяльності та вивчення можливостей виходу на розрахункові величини фрактору, що формують господарську і фрінансову стабільність.

Показники економічної діяльності підприємств створюють передумови для здійснення прогнозування, моделювання, вироблення стратегії забезпечення господарської та фрінансової стабільності підприємств, виконання конкретних розрахунків економічної і соціальної есрективності, заходів спрямованих на її реалізацію.

Узагальнюючи вищезазначене, можна визначити механізм формування системи
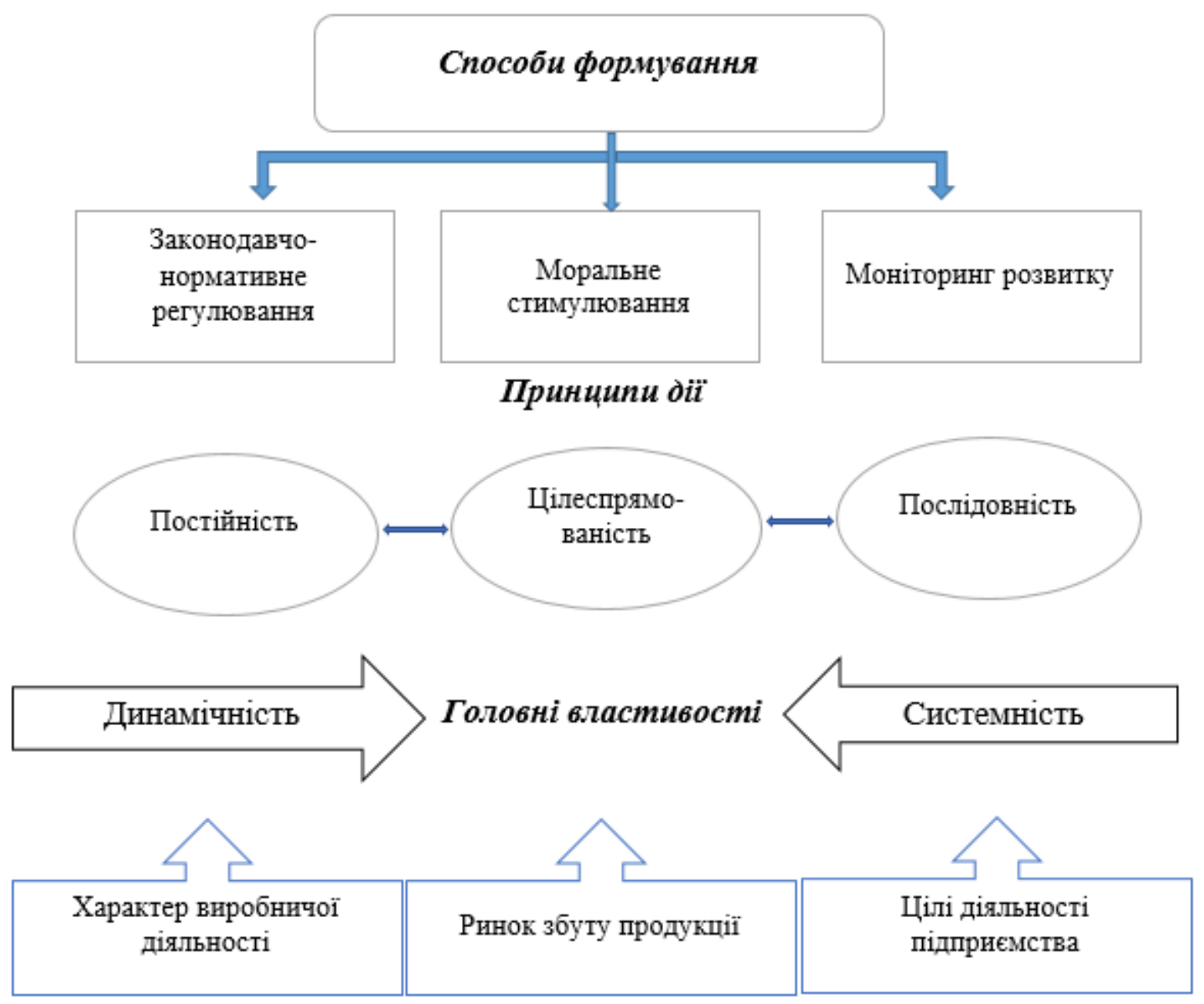

Важелі бплибу

Рис. 3. Напрями та складові механізму розвитку підприємства 
управління розвитком підприємства як сукупність окремих взаємопов'язаних методів, принципів, фрункцій, важелів, заходів, стадій і процедур, спрямованих на зміни якісного стану підприємства (рис. 3). Отже, ключовими напрямками формування системи управління розвитком підприємств харчової галузі, як комплексного механізму характеризуються наступними складовими:

- інструментальна: принципи, методи, способи формування окремих механізмів, які використовуються підприємством за здійснення виробничо-господарської діяльності;

- організаційна: фрорми організації виробництва й організації праці, що забезпечують відповідність їх взаємодії;

- процесна: розглядає діяльність підприємства в динаміці та містить в собі фрункції діяльності;

- самодостатність: саморозвиток системи, як генератора прагнення до самовдосконалення і внутрішньої інформаційно-поведінкової культури підприємства.

Таким чином, найважливіше практичне значення має підхід до формування механізму господарювання як цілісної системи та дає можливість використати її внутрішні закони, ступінь відповідності економічним відносинам й інтересам, виявити взаємозв'язок і взаємозалежність між формами, визначити характер сукупного регулюючого впливу на реалізацію інтересів, встановити шляхи подолання неузгодженості й подальшої гармонізації.

Висновки і пропозиції. Узагальнюючи результати проведених досліджень, можна зазначити, що механізм розвитку господарської діяльності підприємств харчової промисловості $€$ частиною загальної системи управління підприємством, який забезпечує вплив на фрактори формування загального результату діяльності суб'єкта. Формування системи управління розвитком підприємств харчової промисловості дозволить керівникам на практиці використовувати його для забезпечення стабільного фрункціонування та прогнозування розвитку підприємства в майбутньому, за умови удосконалення фрінансово-економічного та організаційного механізмів управління діяльністю підприємств, сприяти досягненню довгострокових цілей, а також стабілізації економіки та підвищенню рівня конкурентоспроможності національних підприємств та економіки держави на світовому ринку.

\section{СПИСОК ВИКОРИСТАНИХ ДЖЕРЕЛ:}

1. Андрійчук В.Г. Економіка підприємств агропромислового комплексу : підручник. Київ : КНЕУ, 2013. 779 с.

2. Арефф'єва О.В., Кузенко Т.Б. Планування економічної безпеки підприємств. Київ : Видавництво Європейського університету, 2005. 170 с.

3. Василенко В.А., Ткаченко Т.І. Стратегічне управління : навч. посібник. Київ : ЦУЛ, 2003. 396 с.

4. Городня Т.А., Мойсеєнко І.П. Економічна та фрінансова діагностика : навч. посібник. Львів : «Магнолія 2006», 2008. 282 C.

5. Гриньова В. М. Державне регулювання економіки. Київ : Знання, 2018. 398 с.

6. Кузьмін О., Мельник О. Основи менеджменту : підручник. Київ : Академвидав, 2003. 416 с.

7. Пащенко О.П. Стратегічне управління розвитком підприємства. Вісник Хмельницького національного універсuтету. 2011. № 2. T. 2. С. 99-103.

\section{REFERENCES:}

1. Andriichuk V. (2013) Ekonomika pidpryiemstv ahropromyslovoho kompleksu [Economics of agro-industrial enterprises]: pidruchnyk [a textbook]. Kyiv: KNEU, 779 p. (in Ukrainian)

2. Arefieva O. \& Kuzenko T. (2005) Planuvannia ekonomichnoi bezpeky pidpryiemstv [Economic security planning of enterprises]. Kyiv: Vydavnytstvo Yevropeiskoho universytetu, 170 p. (in Ukrainian)

3. Vasylenko V. \& Tkachenko T. (2003) Stratehichne upravlinnia [Strategic management]: navch. posibnyk [a textbook]. Kyiv: TsUL, 396 p. (in Ukrainian)

4. Horodnia T. \& Moiseienko I. (2008) Ekonomichna ta finansova diahnostyka [Economic and financial diagnostics]: navch. posibnyk [a textbook]. Lviv: «Mahnoliia 2006», 282 p. (in Ukrainian)

5. Hrynova V. (2018) Derzhavne rehuliuvannia ekonomiky [State regulation of Economy]. Kyiv: Znannia, 398 p. (in Ukrainian)

6. Kuzmin O. \& Melnyk O. (2003) Osnovy menedzhmentu [Fundamentals of management]: pidruchnyk [a textbook]. Kyiv: Akademvydav. (in Ukrainian)

7. Pashchenko O. (2011) Stratehichne upravlinnya rozvytkom pidpryyemstva [Strategic management of enterprise development]. Visnyk Khmel'nyts'koho natsional'noho universytetu, no. 2(2), pp. 99-103. (in Ukrainian) 